Buana Sains Vol 17 No 1: 25 - 32

\title{
PRODUKSI PAKAN FUNGSIONAL MENGANDUNG TIGA SENYAWA BIOAKTIF DARI AMPAS TAHU DENGAN MENGGUNAKAN Mikroba Effective Microorganism-4 DAN Lactobacillus plantarum
}

\author{
Budi Santosa, Eka Fitasari dan Gatut Suliana \\ Fakultas Pertanian Universitas Tribhuwana Tunggadewi
}

\begin{abstract}
Tofu waste is a waste product from tofu processing which is known as high protein sources. Its use as feed has a problem due to the antinutrient content and lower amino acids. Effective microorganism (EM4) is a mixture of some microbes that are used to improve the quality of feed. Lactobacillus plantarum is facultative bacteria heterofermentatif group that has a high ability to ferment carbohydrates. The purpose of this study was to determine the effectiveness of both of these bacteria to ferment tofu waste and its influence on the increase in the content of nutrients and amino acids. This study used a Random Nested Design with 2 factor: Factor 1 was type of microbe (EM4 and Lactobacillus plantarum), factor 2 was the concentration of microbes which consists of 5 levels $(1 \%, 5 \%, 10 \%, 15 \%$, and $20 \%, \mathrm{v} / \mathrm{w})$, each treatments was repeated 3 times. The results showed that the average treatment gave very significant effect on dry matter, anorganic matter, crude fiber, crude protein and had significant effect on crude lipid and gross energy. The treatments of $20 \%$ concentration of Lactobacillus plantarum giving highest yield on gross energy, crude fiber, calcium and fosfor.
\end{abstract}

Keywords : functional food, fermentation, tofu waste, EM-4, Lactobacillus plantarum

\section{Pendahuluan}

Industri tahu merupakan salah satu industri yang memiliki perkembangan pesat. Terdapat 84 ribu unit industri tahu di Indonesia dengan kapasitas produksi mencapai 2,56 juta ton per tahun (Sadzali, 2010). Ampas tahu yang terbentuk berkisar antara $25-35 \%$ dari produk tahu yang dihasilkan (Kaswinarni, 2007). Bobot ampas tahu rata-rata 1,12 kali bobot kedelai kering, sedangkan volumenya 1,5 sampai 2 kali volume kedelai kering (Tarmidi, 2009).

Tahu adalah makanan yang dibuat dari endapan perasan biji kedelai yang mengalami koagulasi. Ampas tahu merupakan limbah dari pengolahan tahu dengan kandungan ampas yang bervariasi, rata-rata 39.2\% . Ampas tahu memiliki kendala dalam penggunaannya sebagai pakan ternak dikarenakan adanya anti nutrisi dan asam amino yang rendah. Anti nutrisi yang ada dalam ampas tahu sama seperti anti nutrisi dalam kedelai, yaitu trypsin inbibitor, hanya saja kadarnya sudah berkurang. Trypsin inhibitor memberikan dampak terhadap penghambatan pertumbuhan sebanyak $30-50 \%$ (Isanga \& Zhang, 2008). Fermentesi dapat mendegradasi molekulmolekul protein menjadi peptide dan asam-asam amino. Trypsin inhibitor juga dapat terdegradasi atau mengalami modifikasi selama proses fermentasi dan kehilangan aktifitas mengikatnya dengan tripsin (Chen et al., 2013).

Pemilihan suatu bahan pakan tidak hanya dipengaruhi oleh kandungan 
protein yang ada dalam bahan pakan, akan tetapi yang terpenting adalah kandungan asam aminonya. Asam amino terbukti dapat meningkatkan penampilan produksi ternak dengan cara mengurangi kandungan protein dan secara tidak langsung dapat menurunkan biaya pakan. Sebagai contoh adalah penggunaan asam amino lysine yang memberikan dampak pada deposisi protein dan pertumbuhan otot, selain itu juga memiliki fungsi lain seperti memperbaiki pencernaan. Demikian pula penggunaan threonin dapat memperbaiki imunitas (Anonymous, 2016). Penggunaan pada ayam broiler, peningkatan kandungan lysine dalam pakan dapat meningkatkan bobot badan (Anonymous, 2016) dan menghasilkan produksi daging dada yang bagus (Barboza et al., 2000).

Fermentasi menggunakan mikroba dilakukan untuk mengatasi kekurangan nutrisi dalam ampas tahu. Fermentasi pada legume terbukti mampu memperbaiki kandungan nutrisi dan komponen fungsional dibandingkan bahan aslinya (Granito et al., 2005, Shekib, 1994). Asam-asam amino bebas dan peptide-peptida bioaktif dapat dilepaskan akibat aktifitas mikroba selama proses fermentasi atau diproses oleh enzim yang dihasilkan oleh mikroba (Korhonen and Pihlanto, 2003). Frias et al (2008) dalam penelitiannya melaporkan bahwa fermentasi tepung kedelai menggunakan Lactobacillus sp (L. plantarum) dapat memecah dan menggunakan protein sebagai sumber nutrisinya, sehingga dapat memperkaya produk fermentasi. Dalam penelitian ini menggunakan mikroba seperti EM4 dan Lactobacillus plantarum. Ampas tahu merupakan pakan sumber protein tinggi dan kaya akan isoflavon. Penggunaan 2 kelompok mikroba tersebut diharapkan mampu menurunkan kandungan anti nutrisi dalam pakan dan meningkatkan kandungan nutrisi pakan.

\section{Materi dan Metode Penelitian}

Penelitian laboratorium dilaksanakan Laboratorium Rekayasa Pangan Universitas Tribhuwana Tunggadewi Malang, Jawa Timur. Bakteri Lactobacillus plantarum diperoleh dari Laboratorium Nutrisi dan Makanan Ternak, Universitas Brawijaya, Indonesia. EM4 merupakan Effective microorganism-4 yang yang mengandung mikroba Lactobacillus casei $1.5 \times 106 \mathrm{cfu} / \mathrm{ml}$, Saccharomyces cerevisiae $1.5 \times 106 \mathrm{cfu} / \mathrm{ml}$, dan Rhodopseudomonas palustris $1.0 \mathrm{x} 106 \mathrm{cfu} / \mathrm{ml}$. Analisa asam amino dilakukan Laboratorium biokimia Universitas Muhammadiyah Malang.

Media Lactobacillus plantarum dibuat dengan cara merebus kentang yang sudah dikupas dan dipotong-potong ke dalam air aquades (perbadingan kentang $200 \mathrm{~g}$ : air $1000 \mathrm{ml}$ ) hingga mendidih dan air menjadi keruh. Larutan kentang disaring menggunakan kain saring ke dalam Erlenmeyer, ditambahkan gula sebanyak $15 \mathrm{~g}$ sambil diaduk di atas kompor listrik. Selanjutnya Erlenmeyer ditutup menggunakan kapas + kertas coklat, diikat kuat menggunakan karet. Sebelum diinokulasi menggunakan Lactobacillus plantarum, semua peralatan dan media disterilisasi menggunakan otoklaf.

EM4 merupakan produksi PT Songgolangit Persada, mengandung 3 jenis mikroba yaitu Lactobacillus casei $1.5 \times 10^{6} \mathrm{cfu} / \mathrm{ml}$, Saccharomyces cerevisiae $1.5 \times 10^{6} \mathrm{cfu} / \mathrm{ml}$, and Rhodopseudomonas palustris $1.0 \times 10^{6} \mathrm{cfu} / \mathrm{ml}$. Untuk pencampuran ke dalam ampas tahu EM4 diencerkan menggunakan aquades. Sebagai contoh untuk kebutuhan $1000 \mathrm{~g}$ ampas tahu dengan konsentrasi EM4 1\% maka EM4 murni diencerkan dengan perhitungan $1 / 100 \times 10 \mathrm{ml}=0,1 \mathrm{ml}$, selanjutnya $0,1 \mathrm{ml}$ EM4 dimasukkan ke dalam gelas ukur $10 \mathrm{ml}$ dan ditambahkan 
aquades hingga mencapai angka $10 \mathrm{ml}$, kemudian baru dicampurkan ke dalam ampas tahu.

Percobaan fermentasi ampas tahu menggunakan perlakuan beberapa jenis mikroba dan konsentrasi yang berbeda disusun berdasarkan Rancangan Acak Tersarang 2 faktor, perlakuan terdiri atas : Faktor I. Jenis Mikroba, terdiri atas 2 level yaitu M1 $=$ Effective Microorganism (EM-4), M2 = Lactobacillus plantarum; Faktor II. Konsentrasi mikroba, terdiri atas 5 level yaitu $\mathrm{K} 1=1 \%, \mathrm{~K} 2=5 \%, \mathrm{~K} 3=10 \%$, $\mathrm{K} 4=15 \% \mathrm{~K} 5=20 \%(\mathrm{v} / \mathrm{m})$ dimana faktor kedua ini tersarang pada faktor pertama (jenis mikroba) dengan 3 ulangan.

\section{Pelaksanaan Penelitian}

Ampas tahu segar diperas airnya, hingga bobotnya berkurang $1 / 4$ nya. Tujuaannya adalah untuk mengurangi kandungan air ampas tahu. Selanjutnya, ampas tahu dikukus selama 30 menit dan didinginkan. Ke dalam ampas tahu yang sudah dingin ditambahkan gula pasir sebanyak $1 \%$, susu skim $5 \%$, kemudian ampas tahu dibagi menjadi dua, separuh diberi inokulum Lactobacillus plantarum dengan konsentrasi sesuai perlakuan serta separuhnya lagi diberi inokulum EM-4 dengan konsentrasi sesuai perlakuan juga. Semua bahan dicampur secara merata kemudian dimasukkan ke dalam plastik kresek dan diikat sampai tidak ada gelembung udara pada plastik tersebut selanjutnya difermentasi pada suhu kamar selama 5 hari. Setelah tiga hari fermentasi, plastik dibuka kemudian ampas tahu diambil dan dikeringkan ke dalam oven dengan suhu $60^{\circ} \mathrm{C}$ sampai kering. Setelah kering kemudian dihaluskan dan diayak. Selanjutnya dilakukan analisa kandungan proksimat paka (kandungan bahan kering, protein kasar, lemak kasar, serat kasar, abu, gross energy, kalsium, dan phosphor)

Analisa Data

Data-data dari parameter yang telah didapatkan hasil dari analisa di laboratorium dianalisis menggunakan analisis sidik ragam pada taraf $\alpha=5 \%$. Apabila hasil dari analisa sidik ragam menunjukkan beda nyata maka dilanjutkan dengan uji BNT ( Gomes dan Gomes, 1984).

\section{Hasil dan Pembahasan}

\section{Pengaruh Perlakuan terhadap Kandungan} Proksimat Pakan

Ampas tahu merupakan sumber energi bagi bakteri yang diperlukan dalam proses pertumbuhannya, apalagi dengan adanya penambahan gula dan skim yang merupakan mineral bagi bakteri sehingga mempercepat aktifitas pertumbuhan bakteri. Berikut ini merupakan hasil analisa terhadap kandungan proksimat pakan, gross energy, mineral kalsium dan fosfor (Tabel 1 dan Tabel 2).

Hasil penelitian pada Tabel 1 menunjukkan bahwa perlakuan rata-rata memberikan pengaruh yang sangat nyata $(\mathrm{p}<0.01)$ terhadap kandungan bahan kering (BK), Abu, protein kasar (PK) dan serat kasar (SK), sementara perlakuan memberikan yang nyata $(\mathrm{p}<0.05)$ terhadap lemak kasar (LK) dan GE dan memberikan pengaruh yang sangat nyata $(\mathrm{p}<0.01)$ pada kadar kalsium dan fosfor (tabel 2). Penggunaan EM4 rata-rata memberikan hasil yang lebih tinggi terhadap kandungan proksimat pakan (BK, Abu, PK, SK, dan LK), sementara Lactobacillus plantarum cenderung rendah kandungan proksimatnya, namun meningkat pada kandungan kalsium dan fosfor. 
B. Santosa, E. Fitasari dan G. Suliana / Buana Sains Vol 17 No $1: 25$ - 32

Tabel 1. Kandungan bahan kering, abu, protein kasar dan serat kasar dari ampas tahu fermentasi

\begin{tabular}{lllll}
\hline Perlakuan & \multicolumn{1}{c}{ BK $(\%)^{* *}$} & \multicolumn{1}{c}{ Abu $(\%)^{* *}$} & PK $(\%)^{* *}$ & \multicolumn{1}{c}{$\mathrm{SK}(\%)^{* *}$} \\
\hline M1K1 & $93,61 \mathrm{c}$ & $3,67 \mathrm{c}$ & $14,39 \mathrm{a}$ & $23,11 \mathrm{~b}$ \\
M1K2 & $93,38 \mathrm{c}$ & $3,71 \mathrm{c}$ & $14,36 \mathrm{a}$ & $23,47 \mathrm{~b}$ \\
M1K3 & $93,61 \mathrm{c}$ & $3,79 \mathrm{c}$ & $15,01 \mathrm{~b}$ & $21,72 \mathrm{~b}$ \\
M1K4 & $93,42 \mathrm{c}$ & $3,97 \mathrm{~d}$ & $14,85 \mathrm{~b}$ & $18,44 \mathrm{a}$ \\
M1K5 & $91,34 \mathrm{a}$ & $3,53 \mathrm{~b}$ & $14,01 \mathrm{a}$ & $18,11 \mathrm{a}$ \\
M2K1 & $91,73 \mathrm{a}$ & $3,52 \mathrm{~b}$ & $14,50 \mathrm{a}$ & $17,31 \mathrm{a}$ \\
M2K2 & $93,36 \mathrm{c}$ & $3,33 \mathrm{~b}$ & $15,39 \mathrm{a}$ & $19,32 \mathrm{a}$ \\
M2K3 & $92,85 \mathrm{~b}$ & $3,23 \mathrm{a}$ & $15,08 \mathrm{a}$ & $21,52 \mathrm{a}$ \\
M2K4 & $92,09 \mathrm{a}$ & $3,01 \mathrm{a}$ & $13,53 \mathrm{a}$ & $25,07 \mathrm{~b}$ \\
M2K5 & $92,26 \mathrm{~b}$ & $3,13 \mathrm{a}$ & $13,66 \mathrm{a}$ & $23,23 \mathrm{~b}$ \\
\hline Uji F & $\mathrm{P}<0.01$ & $\mathrm{P}<0.01$ & $\mathrm{P}<0.01$ & $\mathrm{P}<0.01$ \\
Nilai BNT & 0,76 & 0,22 & 1,07 & 4,11
\end{tabular}

Ket: **a,b,c,d,e,f Notasi yang berbeda menunjukkan bahwa perlakuan memberikan pengaruh yang sangat nyata terhadap variabel pengamatan $(0<0.01)$

\section{Pengaruh perlakuan terhadap bahan kering}

Bahan kering merupakan bagian dari suatu bahan atau pakan setelah dikurangi kandungan air. Di dalam bahan kering terdapat berbagai kandungan bahan organic (protein, serat, lemak, karbohidrat, asam amino) dan bahan anorganik (mineral) (Tillman dkk, 1991). Pengukuran bahan kering penting untuk dilakukan karena semakin tinggi kandungan bahan kering, berarti kandungan nutrisi dalam pakan juga makin tinggi, dan hal ini sangat penting perannya dalam penyusunan pakan ternak, dimana kebutuhan ternak adalah berdasarkan kandungan bahan kering. Apabila kandungan air dalam suatu pakan tinggi, maka akan menyebabkan masalah bagi ternak, diantaranya akan menyebabkan kembung perut yang dapat berakibat pada kematian, contohnya pada kelinci dan ternak ruminansia. Fermentasi menggunakan EM4 cenderung menunjukkan kandungan bahan kering ampas tahu fermentasi yang lebih tinggi pada perlakuan dibandingkan menggunakan Lactobacillus plantarum.
Perlakuan pada M1K1 hingga M1K4 menunjukkaan pengaruh yang signifikan terhadap bahan kering ampas tahu fermentasi $\quad(p<0.01), \quad$ kemudian cenderung menurun pada perlakuan M1K5. Hal ini diduga disebabkan karena jenis mikroba dalam EM4 yang terdiri dari bakteri dan jamur yaitu Saccharomyces cerevisiae dan Rhodopseudomonas palustris yang diduga menghasilkan hifa dalam proses fermentasinya sehingga menambah kandungan bahan kering. Namun hasil ini kemudian menurun pada perlakuan EM4 konsentrasi 20\%. Adanya penurunan kandungan bahan kering saat fermentasi, diduga disebabkan adanya perombakan bahan kering substrat dimana bahan organik mengalami penguraian oleh mikroorganisme, Penelitian ini juga sejalan dengan yang dilaporkan oleh Umiyasih dan Anggraeny (2008) bahwa Selama proses fermentasi bahan kering akan diurai sebagai sebagai sumber energi atau bahan pembentuk sel baru sehingga kandungan bahan keringnya akan menurun. Pada perlakuan menggunakan L. plantarum menunjukkan hasil yang 
berbeda sangat nyata pada perlakuan M2K2 dimana kandungan bahan kering ampas tahunya lebih tinggi dibandingkan pada konsentrasi $10 \%, 15 \%$, dan $20 \%$. Hal ini menunjukkkan bahwa terjadi penguraian yang lebih banyak pada ampas tahu selama proses fermentasi yang diakibatkan semakin tingginya konsentrasi L. plantarum.

\section{Pengarub perlakuan terhadap protein kasar}

Hasil penelitian menunjukkan bahwa perlakuan menggunakan EM4 menghasilkan pengaruh yang sangat signifikan $(\mathrm{p}<0.01)$ terhadap kandungan protein kasar. Hasil yang tinggai dicapai pada penggunaan EM4 hingga konsentrasi 15\%. Hal ini berkorelasi dengan jenis mikroba yang lebih beragam pada kandungan EM4. Sedangkan hasil fermentasi menggunakan L. plantarum cenderung lebih rendah. Rendahnya protein kasar ampas tahu fermentasi Lactobacillus plantarum, sebenarnya juga merupakan indikasi bahwa pakan tersebut telah diproses oleh mikroba. Hal ini senada dengan hasil penelitian Frias $e t$ al (2008), konsentrasi ekstrak protein dari kedelai mentah adalah $320 \mathrm{mg}$ protein per gram, sementara pada produk fermentasi liquid oleh Lactobacillus plantarum adalah $102.7 \mathrm{mg}$ protein /g, yang dapat diartikan selama proses fermentasi menyebabkan penurunan kandungan protein, tetapi rata-rata meningkatkan kandungan asam amino. Selama proses fermentasi diduga bahwa mikroorganisme dan enzim yang dihasilkan menghidrolisa protein yang larut dalam air (protein soluble) akibatnya peptide-peptida akan terbentuk.

Rendahnya kandungan protein yang dihasilkan oleh L. plantarum ternyata tidak berkorelasi dengan hasil asam amino yang dihasilkan. Seperti yang dilaporkan oleh Fitasari dan Santosa (2016), penggunaan L. plantarum mampu meningkatkan produksi asama amino dibandingkan EM4. Konsentrasi 20\% dari Lactobacillus plantarum menghasilkan $1612.72 \mathrm{mg} / 100 \mathrm{gr}$ valin, $587.44 \mathrm{mg} / 100$ gr metionin, $1694.62 \mathrm{mg} / 100$ gr isoleusin, $2123.93 \mathrm{mg} / 100 \mathrm{gr}$ leusin, $820.90 \mathrm{mg} / 100$ gr tirosin, 1468.8 $\mathrm{mg} / 100 \mathrm{gr}$ fenilalanin, $832.94 \mathrm{mg} / 100 \mathrm{gr}$ histidin, $1632.66 \mathrm{mg} / 100$ gr lysin, $1858.79 \mathrm{mg} / 100$ gr arginin, 607.05 $\mathrm{mg} / 100 \mathrm{gr}$ triptofan, $566.84 \mathrm{mg} / 100 \mathrm{gr}$ glutamin, dan $545.78 \mathrm{mg} / 100$ gr sistin.

Seperti dikatakan oleh Korhonen dan Pihlanto (2003), akibat kerja dari mikroba selama proses fermentasi, dapat melepaskan asama amino bebas dan peptide-peptida bioaktif. Hasil penelitian di atas sejalan dengan penelitian Wang and Cavins (1989), bahwa proses pembuatan tahu menyebabkan terjadinya peningkatan pada asam amino valin, methionin, isoleusin, leusin, tyrosin, dan phenilalanin. Amadou et al. (2010) melaporkan bahwa proses fermentasi kedelai oleh Lactobacillus plantarum melepaskan asam-asam amino dan pembentukann peptide yang memiliki berat molekul rendah. Dibandingkan dengan control (kedelai tanpa fermentasi), hasil fermentasi menyebabkan peningkatkan asam amino valine, isoleusin, dan leusin.

\section{Pengarub perlakuan terbadap serat kasar}

Perlakuan EM4 dan L. plantarum memberikan pengaruh yang sangat nyata terhadap kandungan serat kasar ampas tahu fermentasi (Tabel 1). Diketahui bahwa pada proses fermentasi selama 5 hari, konsentrasi EM4 15\% dan 20\% menunjukkan penurunan terhadap kandungan serat kasar ampas tahu, hal ini disebabkan karena adanya 2 jenis jamur pada EM4 (Saccharomyces cerevisiae dan Rhodopseudomonas palustris) diduga lebih efektif dalam menggunakan serat kasar, yang mengakibatkan penurunan 
kandungan serat kasar pada ampas tahu fermentasi. Sedangkan pada fermentasi oleh L. plantarum, konsentrasi 15\% dan $20 \%$ menyebabkan kandungan serat kasar ampas tahu masih mengalami kenaikan serat kasar. Hal ini disebabkan karena ampas tahu mengandung selulosa yang cukup tinggi, ditambah dengan adanya penambahan gula dan skim yang akan menambah asam amino pada pakan sehingga mempercepat pertumbuhan mikroba.

Tabel 2. Kandungan Lemak kasar, gross energy, kalsium, dan forfor dari ampas tahu fermentasi

\begin{tabular}{lllll}
\hline Perlakuan & \multicolumn{1}{c}{$\mathrm{LK}(\%) *$} & $\mathrm{GE}(\mathrm{kkal} / \mathrm{kg}) *$ & $\mathrm{Ca}(\%) * *$ & $\mathrm{P}(\%) * *$ \\
\hline M1K1 & $20,2 \mathrm{c}$ & $4862,75 \mathrm{~b}$ & $1,07 \mathrm{a}$ & $1,02 \mathrm{a}$ \\
M1K2 & $20,29 \mathrm{c}$ & $4723,93 \mathrm{~b}$ & $1,11 \mathrm{a}$ & $1,04 \mathrm{~b}$ \\
M1K3 & $20,30 \mathrm{c}$ & $4699,22 \mathrm{~b}$ & $1,15 \mathrm{~b}$ & $1,08 \mathrm{c}$ \\
M1K4 & $20,87 \mathrm{c}$ & $4797,81 \mathrm{~b}$ & $1,19 \mathrm{c}$ & $1,08 \mathrm{c}$ \\
M1K5 & $19,35 \mathrm{~b}$ & $4778,77 \mathrm{~b}$ & $1,25 \mathrm{~d}$ & $1,11 \mathrm{e}$ \\
M2K1 & $18,51 \mathrm{~b}$ & $4469,42 \mathrm{a}$ & $1,12 \mathrm{~b}$ & $1,05 \mathrm{~b}$ \\
M2K2 & $19,84 \mathrm{c}$ & $4725,49 \mathrm{~b}$ & $1,14 \mathrm{~b}$ & $1,06 \mathrm{~b}$ \\
M2K3 & $17,91 \mathrm{a}$ & $4632,71 \mathrm{a}$ & $1,20 \mathrm{c}$ & $1,09 \mathrm{~d}$ \\
M2K4 & $17,48 \mathrm{a}$ & $4552,06 \mathrm{a}$ & $1,26 \mathrm{~d}$ & $1,12 \mathrm{e}$ \\
M2K5 & $16,7 \mathrm{a}$ & $4899,74 \mathrm{~b}$ & $1,31 \mathrm{e}$ & $1,14 \mathrm{f}$ \\
\hline Uji F & $\mathrm{P}<0.05$ & $\mathrm{P}<0.05$ & $\mathrm{P}<0.01$ & $\mathrm{P}<0.01$ \\
Nilai BNT & 1,29 & 219,94 & 0,04 & 0,02 \\
\hline Ket: & & &
\end{tabular}

Ket: *a,b,c Notasi yang berbeda menunjukkan bahwa perlakuan memberikan pengaruh yang nyata terhadap variabel pengamatan $(0<0.05) ; * *_{a, b, c, c, e, f}$ Notasi yang berbeda menunjukkan bahwa perlakuan memberikan pengaruh yang sangat nyata terhadap variabel pengamatan $(0<0.01)$

Pengaruh perlakuan terhadap Lemak kasar

Perlakuan EM4 dan L. plantarum berpengaruh nyata terhadap lemak kasar pada ampas tahu fermentasi. Berdasarkan Tabel 2 pada konsentrasi EM4 1\% hingga 15\% terjadi kenaikan yang tinggi pada kandungan lemak kasar dan kemudian menurun pada konsentrasi 20\%. Dibandingkan dengan perlakuan $L$. plantarum, bahwa hasilnya terhadap lemak kasar adalah lebih rendah. Hal ini diduga karena adanya jenis mikroba yang lebih kompleks pada EM4 sehingga lebih efektif dalam memecah lemak kasar. Hal ini menunjukkan bahwa EM4 memiliki aktifitas lipase yang lebih tinggi. Lipase adalah enzim yang dapat larut dalam air yang bekerja dengan cara mengkatalisis ikatan ester dalam substrat lipid yang tidak larut air seperti trigliserida berantai panjang. Lipase dari bakteri kebanyakan diproduksi secara ekstraseluler. Menurut Kasmidjo (1990) lemak tidak digunakan sebagai sumber energi oleh mikroorganisme dalam proses fermentasi akan tetapi karbohidrat yang digunakan sebagai sumber energinya, sehingga memungkinkan dalam proses perombakan karbohidrat yang berlangsung dapat menaikkan lemak kasar. Adanya penurunan lemak kasar pada EM4 konsentrasi $20 \%$ dan L.plantarum 10\% diduga bahwa mikroba sudah melewati fase stationer sehingga mengalami penurunan dalam perombakan substrat.

\section{Pengaruh perlakuan terhadap gross energy}

Lactobacillus plantarum dan Lactobacillus casei (mikroba yang terdapat pada EM4) merupakan bakteri fakultativ anaerob yang mampu mencerna heksosa menjadi 
asam laktat, ethanol, dan asam asetat (Anonimus, 2014). Tabel 2 menunjukkan bahwa perlakuan memberikan pengaruh yang berbeda nyata $(\mathrm{p}<0.05)$ terhadap kandungan gross energy pakan. Perlakuan menggunakan EM4 rata-rata menghasilkan kandungan gross energy yang tinggi pada konsentrasi 1\% hingga $20 \%$. Hal ini menunjukkan bahwa 3 jenis mikroba pada EM4 sangat efektif dalam merombak karbohidrat dalam ampas tahu. Sedangkan perlakuan menggunakan L. plantarum mulai signifikan dalam meningkatkan gross energy pada konsentrasi 20\%. Hal ini menunjukkan bahwa pada konsentrasi ini bakteri mengalami puncak perkembangan (fase $\log$ ), untuk fase stationernya masih belum diketahui, karena tidak ada konsentrasi yang lebih tinggi dari 20\%. Adanya penambahan skim dan gula menyebabkan massa mikroba menjadi semakin banyak sehingga menjadi lebih efektif dalam mendegradasi ampas tahu untuk menghasilkan energy. Menurut Pramono dkk (2003) Lactobacillus mengalami pertumbuhan yang optimum pada $\mathrm{pH}$ 6,8 dan waktu 20 jam.

\section{Pengarub perlakuan terbadap mineral}

Perlakuan menunjukkan pengaruh yang sangat signifikan pada kandungan abu, kalsium, dan fosfor $(p<0.01)$. Pada tabel 2 terlihat bahwa perlakuan menggunakan EM4 menunjukkan peningkatan pada kandungan abu. Abu merupakan kandungan bahan kering setelah dikurangi bahan organic. Abu merupakan jumlah dari kandungan mineral secara umum. Sedangkan perlakuan menggunaka L. plantarum menunjukkan kandungan abu yang lebih rendah dibandingkan pada EM4. Rendahnya kandungan abu oleh L. plantarum diduga karena selama proses fermentasi terjadi peningkatan bahan organic akibat perombakan substrat oleh mikroba sehingga menurunkan kadar abu. Semakin sedikit bahan organic yang terdegradasi maka akan semakin sedikit pula penurunan kandungan abu secara proporsional, sebaliknya semakin banyak bahan organic yang terdegradasi maka akan semakin banyak pula kandungan abu secara proporsional. Hal ini sejalan dengan pengamatan variable nutrisi lainnya dimana pada konsentrasi mikroba yang semakin tinggi menyebabkan peningkatan pula kandungan nutrisi dari ampas tahu fermentasi (BK, LK, SK, PK, GE). Namun, hasil yang lebih spesifik pada kandungan kalsium dan phosphor menunjukkan bahwa akibat dari proses fermentasi menyebabkan peningkatan kandungan keduan kedua bahan ini dengan semakin tingginya konsentrasi mikroba. Peningkatan kandungan fosfor dan kalsium dalam bahan sangat penting dalam pembuatan formulasi pakan ternak karena berfungsi tinggi dalam peningkatan pertumbuhan ternak.

\section{KESIMPULAN}

Berdsarkan hasil penelitian dapat diambil kesimpulan :

a. Fermentasi ampas tahu menggunakan EM4 memberikan pengaruh yang sangat nyata terhadap kandungan bahan kering, abu, serat kasar, protein kasar, serat kasar, dan lemak kasar.

b. Fermentasi ampas tahu menggunakan Lactobacillus plantarum memberikan pengaruh yang nyata terhadap kandungan Gross Energi dan sangat nyata terhadap kandungan kalsium dan fosfor.

c. Perlakuan Lactobacillus plantarum pada konsentrasi $20 \%$ memberikan hasil tertinggi terhadap kandungan gross energy, kalsium, dan fosfor. 


\section{DAFTAR PUSTAKA}

Amadou, I., M. T. Kamara, A. Tidjani, M. B. K. Foh, and Guo-Wei L. 2010. Physicochmical and nutritional Analysis of fermented Soybean Protein Meal by Lactobacillus plantarum Lp6.

World Journal of Dairy \& Food Sciences 5 (2) $114-118$

Anonimus, 2014. Lactobacillus plantarum. www.wikipedia.com. Diakses tanggal 21 Maret 2017

Anonymous, 2016. Amino Acid Nutrition of The Broiler Chicken Update on Lysine, Threonine,

and Other Amino Acids. Ajinomoto Animal Production. pp 3-4

Barboza, W.A., H.S., Rostagno, L.F.T. Albino, and P.B. Rodrigues. 2000. Nutritional Requirement of Digestible Lysine for Broiler Chickens. Revista Brasileira de Zootecnia 29 : 1098-1102

Chen, L., R. L. Madl, P. V. Vadlani, L. Li, and W. Wang, 2013. Value - Added Products from

Soybean : Removal of Anti-Nutritional Factors via Bioprocessing. INTECH open science, open minds. www.intechopen.com

Fitasari, E. dan Santosa, B. 2016. Efek Fermentasi oleh Lactobacillus plantarum terhadap

Kandungan Asam Amino Ampas Tahu. Disampaikan dalam Seminar Nasional Bioteknologi IV di Universitas Gadjah Mada 29 Oktober 2016.

Frias, J., Y. S. Song, C. M. Villaluenga, E. G D. Mejia, and C. V. Valverde, 2008. Immunoreactivity and Amino Acid Content of Fermented Soybean Products. Journal of Agricultural and Food Chemistry, 56 : 99105

Gomez, K. A. and Gomez, A.A., 1984. Statistical Procedures for Agricultural Research, second edition. John Wiley \& Sons, A WileyInterscience Publication. USA
Granito, M., A. Torres, J. Fias, M. Guerra, and V. V. Conception, 2005. Influence of Fermentation on The Nutritional Value of two Varieties of Vigna sinensis. European Food

Research and Technol., 220: 176-181

Isanga, J. \& zhang, G. 2008. Soybean Bioactive Components and Their Implications to Health-a

review. Food reviews International, 24, 252-276

Kasmidjo, 1990. Tempe, Mikrobiologi dan Biokimia Pengolahan serta Pemanfaatannya. Soegija Pranata Press. Semarang

Kaswinarni,Fibria. 2007. Kajian Teknis Pengolahan Limbah Padat dan Cair Industri Tahu. Tesis. Universitas Diponegoro. Semarang.

Korhonen, H. and A. Pihlanto. 2003. Food Derived Bioactive Peptides Opportunities for

Designing Future Foods. Current Pharmaceutical Design. 9(16): 1297-308.

Sadzali, Imam. 2010. Potensi Limbah Tahu Sebagai Biogas. Jurnal UI Untuk Bangsa Seri

Kesehatan. Sains dan Teknologi 1(12)

Shekib, L. A. 1994. Nutritional Improvement of Lentils, Chikpea, Rice, and Wheat by Natural

Fermentation. Plant Foods Hum, Nutr, 46, 201-2015

Tarmidi, Anna Rochana. 2009. Teknologi Pakan Dalam Menunjang Industri Peternakan di Indonesia. Pengembangan Inovasi Pertanian 2(3).

Tillman, D., H. Hartadi, S. Prawirokusumo, S. Reksohadiprodjo dan S.Lebdosukojo.1991. Ilmu Makanan Ternak Dasar.Gadjah mada University Press, Yokyakarta.

Umiyasih, U. dan Y. N. Anggraeny., 2008. Pengaruh Fermentasi Saccharomyces Cerevisiae Terhadap Kandungan Nutrisi Dan Kecernaan Ampas Pati Aren (Arenga pinnata MERR.). Disampaiakan dalam Seminar Nasional Teknologi Peternakan dan Veteriner 2008.

Wang, H. L. and J. F. Cavins. 1989. Yield and Amino Acid Composition of Fractions Obtained

During Tofu Production. Cereal Chem. 66 (5):359-361 